\title{
Blame the Parents? Challenges for Parent-Focused Programmes for Families of Gang-Involved Young People
}

\author{
Judith Aldridge*, Jon Shute, Robert Ralphs and Juanjo Medina \\ Centre for Criminological and Socio-Legal Research, University of Manchester, Manchester, UK
}

Parent-focused interventions are a potentially effective tool for preventing and reducing gang involvement, although the challenges of delivering such services are considerable. Drawing from data collected over 26 months for the ethnographic study, Youth Gangs in an English City, including interviews with parents of gang-involved young people, we identify potential obstacles. These include: psychological barriers to the participation of parents relating to perceived denial, stigma and blame; and possible counter-productivity of interventions. Strategies to minimise these are discussed. (C) 2009 The Author(s). Journal compilation (c) 2009 National Children's Bureau and Blackwell Publishing Limited.

Keywords: crime, intervention, parenting, policy and practice, youth.

\section{Introduction}

\section{Youth gangs and their effects}

Delinquent youth gangs have been identified and studied globally (Hagedorn, 2008), including the UK (Pitts, 2008; Sharp and others, 2006), and although the field is characterised by dissensus regarding nomenclature, definition and measurement (Short and Hughes, 2006), greater consensus exists regarding the serious deleterious effects of membership on individuals and the multiply marginalised communities they inhabit (see Klein and Maxson, 2006, for a review).

Gang membership is not synonymous with offending (Sharp and others, 2006) but is a risk factor for greater involvement in and severity of offending relative to periods of nonmembership (Thornberry and others, 1993). Similar amplificatory effects are seen for risky health behaviour (Smith and Bradshaw, 2005) and serious victimisation (Miller, 1998; Taylor and others, 2007). Gang membership further increases social exclusion for members (Thornberry and others, 2003) and is associated with increased risk for violence and dysfunction in nested family, school and community contexts (Hawkins and others, 1998; Pitts, 2008; Vigil, 2007).

\section{Family-level risk factors for gang involvement}

As a dependent variable, gang membership is the product of cumulative risk across a range of interlocking personal and ecological domains (Howell and Egley, 2005; Thornberry, 1998); and its risk factors generally comprise a subset of predictors for serious and violent offending (Howell, 1998). One important risk domain relates to the family. The most consistent 
empirical evidence points to the importance of family process variables, particularly parental supervision and monitoring (Klein and Maxson, 2006). High parental supervision may simply limit the opportunity for young people to associate with antisocial peers, but to the extent that it also indexes the quality of the caregiver-child relationship (e.g. the child's willingness to accurately disclose information; practices of negotiating and enforcing 'house rules' relating to leisure time), supervision may also indicate the perceived (low) attractiveness of antisocial peers (e.g. Warr, 2007). Vigil (2007), describing extensive ethnographic work in a gang-affected Los Angeles community, usefully summarises the family variables that 'push' youth onto the street and into gangs as: permissive or authoritarian parenting, absent and abusive men, and lack of (parental) community social ties. More directly, a commonly stated reason for joining gangs is having family members already in the gang (Maxson and Whitlock, 2002; Thornberry and others, 2003), and becoming involved may, for some, be a fairly simple extension of associating with existing gang-involved friends and family (see also Thornberry, 1998).

\section{The potential of family intervention to prevent and reduce gang involvement}

The serious negative consequences of gang involvement have been used to justify programmatic intervention for over 70 years (Howell, 2000; Klein and Maxson, 2006), but despite known family-level risk, interventions targeting the family have been peripheral to most major gang programmes, where detached youth work, community organisation and coordinated suppression dominate (Shute, 2008). Candidate programmes that focus on improved parental education, child behaviour management and relationship quality are suggested by a confident effectiveness literature with regard to the prevention and reduction of serious antisocial behaviour (Welsh and Farrington, 2006), although the evidence-base is hampered by the habit of not employing gang involvement as a dependent variable (see Tremblay and others, 1996, for an exception). Although a prima facie case can be made for family intervention as a gang reduction tool, there remain a number of potential problems with the approach.

First, policy misdirection: an inappropriate responsibilisation of parents and families can divert attention from the multi-domain nature of risk and the importance of structural/contextual factors in shaping family processes (Bronfenbrenner, 1979). Relatedly, a critical literature has emerged to question the efficacy of recent English policy emphasis on the legal compulsion of parenting support via Parenting Orders and Family Intervention Projects (Burney and Gelsthorpe, 2008; Nixon and Parr, 2008).

Second, there are considerable difficulties in operationalising, from an assessment and service targeting perspective, 'risk for gang involvement' or even actual gang involvement. Authors have argued that the 'gang' label - often officially defined by admission, suspicion and/or simple association with offending youth - is both slippery (Aldridge and others, 2008) and potentially dangerous (Hallsworth and Young, 2008) from a labelling perspective. Gang membership is not synonymous with offending (Ralphs and others, 2009; Sharp and others, 2006), and it may be safer to target demonstrable antisocial behaviour than real or suspected group affiliation in isolation (Bullock and Tilley, 2008).

Third, offering (or compelling - see Holt, 2008) intensive family support to socially excluded populations can be challenging in relation to securing engagement and minimising attrition (Clarke and Churchill, 2007), partly due to issues relating to the stigma associated with 
accepting (or being seen to need) help and the guilt that can follow from accepting responsibility for a child's behaviour (Ghate and Ramella, 2002).

\section{Focus of this paper}

In the UK context, offering evidence-based family intervention to prevent and reduce gang involvement would seem to be the logical endpoint of substantive and enduring policy interest in holding parents responsible for the (bad) behaviour of their children (Koffman, 2008), in parenting support programmes (Moran and others, 2004) and in delinquent youth groups as a focus for government concern (Youth Justice Board 2007). This is evident in the recent proliferation of government-sponsored initiatives to deal with youth offending that focus on 'whole family' approaches (Nixon and Parr, 2008). It is therefore of interest to understand the perceptions and experiences of parents of young people who have been defined as gang involved or 'at risk' of gang involvement. This paper, proceeding from interviews with such parents, identifies: (i) the general perceptions of parent-focused interventions, including possible barriers to engagement and the ways in which they might be overcome; and (ii) the question of how best to target interventions, given the problematic nature of the 'gang' label.

\section{Methods}

The analyses described here are based on a 26-month ethnographic study that took place from 2005 to 2008 in Research City, an anonymous English city. Alongside ethnographic observation, the research incorporated 115 interviews with gang members, associates (friends, relatives, romantic partners) and key informants. Much of the data for the analyses contained here came from two focus group interviews with parents of gang and non-gang youth, and eight interviews with parents of gang members using a specially prepared interview schedule aimed at assessing their views towards parenting interventions. Unless otherwise specified, quotes are drawn from these 'gang parents' interviews. Interviews usually took place in the parents' homes, and were conducted by specially trained interviewers identified from within the communities in which research took place. Interviews were recorded and transcribed, and analysed thematically using a 'grounded' approach.

\section{Results}

Many gang members referred to an unwritten rule for keeping the family - especially mothers - out of 'gang trouble'. In reality, the rule was regularly transgressed, and mothers were, ironically, often most affected. Each of the parents we interviewed told stories of harassment, threats and actual violence they and members of their family experienced, directly connected, as they saw it, to their child's gang involvement - a view not inconsistent with gang members themselves: 'If you want to be in a gang, make sure your family does too, 'cause your family will get it' (18-year-old gang member). Nevertheless, our interviews with parents revealed considerable opposition to the idea of parenting interventions geared towards helping them with their gang-involved children, alongside numerous barriers to getting parents onside with these interventions.

\section{Parents perceive but reject blame}

The perception that parents of gang-involved children could not - by definition - be 'good' parents was common, as illustrated in this focus group interview with non-gang parents: 
The parents don't give a monkey's, it's like having a dog, they open the door, let them out and they don't care what they're up to until they come in. And you go to the parents' door and you get more off the parents than you do off the kids.

The parents of gang-involved children understood that others sought to blame them. This mother perceives the stigma of having a son who is a gang member came directly from others in her neighbourhood:

Going to police stations every five minutes or sat in friggin court from morning till night or police running up and down my fucking house [...] or running to prison every five minutes, feel degraded, people looking at me like I'm a piece of shit. [...] I don't know, I was talking to one of [the neighbours] the other day, and they say, 'Oh you shouldn't feel no way, the police are always at somebody's house round here', and I thought: when I've gone is that what you're going to be saying to the next neighbour, saying, oh did you see the police going to her house? You know what people are like. [Laughter]

Parents were keen to present themselves as not responsible for a child's gang involvement. Even at the point when this mother can no longer deny her son's criminal activity, she presents herself as still a good parent by setting house limits on his criminal activities:

[Interviewer: Were you aware that he was out there committing crime?] Well he had to be doing something didn't he? I mean I'm not gonna sit here and deny it, he's come in with a new pair of trainers on his feet and I never bought them and his Dad never bought them and new clothes, he's had to have been going out doing crime to get them. He's not working, but like I said my house was raided on numerous occasions and the police never ever found anything in my house. [...] They never ever found anything in mine coz he'd been told: don't bring your ill gotten goods into my house, and that's what he was told.

Parents often saw their impact on a child's gang involvement as insignificant compared to other factors - typically, lack of job opportunities and the influence of delinquent peers and suggested that the correct focus for intervention should be the child. For this mother, the factors that led to her son's gang activity were more powerful than any positive force she could exert as a mother to prevent it:

I had to do everything I could in my powers to try and save him. But unfortunately for me it just did not work do you understand me? The strength that, the powers that are out there are stronger for him.

Typically, parents were opposed to parenting interventions, some vehemently, arguably precisely because of their fierce rejection of blame. Indeed, the idea of helping parents to be 'better parents' was seen as misplaced; instead, what they suggested would help them as parents would be to help their children. This mother was affronted and angry after an offer of a parenting course by the courts, which she rejected outright:

One time I went to court with [son's name] and he's up for weed. And this magistrate woman wanted to give me what was it? Some parental skill course, right? And I heard this and I thought, no this can't be right. I shouted out to the solicitor, he's telling me to be quiet and I said no, I won't. I said, 'Excuse me, what did that woman just say?' [...] I said, well I'm very sorry, you can tell the woman I'm not doing it love, I really will not be attending. [...] He was smoking weed, a £10 [bag of] weed was what he was taken to court for and the woman's telling me I need some parenting. I think the 
woman needs parental skills. [...] Let me tell you, I was so vexed about it, the woman knew nothing about me as a person.

\section{Criminally involved parents and the 'perks' of gang members in the family}

A minority of parents may consider the gang involvement of a child to have benefits for them: in terms of status, perceived security for themselves and their families, or even materially. These parents may therefore struggle wholeheartedly to discourage a child's gang involvement if they perceive that they or their families will suffer when that involvement ends, therefore potentially compromising the effectiveness of parenting interventions. Most of the parents we spoke to were forthright in rejecting the possibility that they had benefited in any way from the gang involvement of a child. However, this mother describes an encounter with another parent who was given money by her gang-involved son to keep information from the police:

I remember one woman telling me how she sat there with her son and his friends plotting to get some guy, and they actually got this guy, yeah? And they bought her stuff to keep her quiet. And I was so shocked and disgusted and I said, you what, how do you sleep at night?

This woman's brothers were gang members and gang involvement was common in her extended family. Here she discusses the 'perks':

Our families - brothers, uncles, dads, whatever - are known throughout Research City. So even though we are female, we know that - we're not, you know, untouchable - but we are in a certain respect, because we've got back-up. No one will - they can't take the piss basically because they know they'll get - they'll get it.

The criminal/gang involvement of a parent is likely to prove a substantial barrier to engaging them effectively in a parenting intervention. Our research found evidence of second-generation gang involvement within families: some parents of gang members were criminally involved, active or ex-gang members themselves. This father of a gang member acknowledges his own criminal past: 'I've still got the experience of being an elder, in lets say, gangsterism, bad man business d'ya know what I mean, crime'. This mother explains that her son's father provided him with a model of gang-related activities:

And then he [her son's father] would have all his friends - I'm getting mad you know - all his friends in the house and they were the guys off the estate. [...] He thought, being a bachelor, well he's come to live with me now, his friends can come and chill in the house and he'll buy things off the friends, stolen goods. [...] Kids observe it all and he was confused - well my dad's telling me not to do this and he's buying things off these people and he knows what them boys are doing out on the street and there were a lot of them, gang members.

\section{Mistrust of statutory agencies}

We observed an 'us versus them' attitude that gang parents held to agencies of the state, including criminal justice agencies (police, courts) and social welfare, education and health agencies (termed 'statutory agencies'). Parents felt that official responses to them betrayed a fundamental misunderstanding of the conditions of their lives. This mother criticised criminal justice officials who doled out punishment without understanding the material circumstances of perpetrators: 
I've been to court more time with [her son] than I care to bloody remember yeah? You go in there and there's all these bloody solicitors and all these - magistrate or judge or whatever. And all these people are snobs. They've been to private schools [...] They have no real idea of our life, they have no real idea about being poor. Whether you're poor and white, whether you're poor and Asian, whether you're poor and black, they have no idea. They've no idea to know what its like to wake up fucking hungry and cold. They've no idea about having no clothes or shoes on your feet. They've no idea whatsoever. So all they see is a criminal.

This perception that officials fundamentally misunderstood them extended to those staffing interventions aimed at helping them to be better parents, as this mother illustrates:

This course was aimed at troublesome teenagers, and these women didn't have a clue. They all had kids but they had no idea what having a really naughty kid was like, it was more, 'well if they come in 10 minutes late, you have to decide what their punishment's going to be'. And it's like, no he's come in a week late, what do I do then? Some of these kids are bad, one of the women, her kid had set her on fire while she was in bed asleep, and she woke up on fire. She said, "how do I deal with that?' and they were like ... 'right, let's change the subject, we'll go to this mum now, was your daughter in on time?'.

Parenting interventions therefore need to take into account that the problems faced by families with gang-involved children are often at the extreme end. Interventions geared to families with lower-level problems are unlikely to engender parents' confidence that those staffing the intervention understand the exceptional nature of their problems.

The parents we interviewed perceived agency staff to be uncommitted, unprofessional, and as providing inadequate or flawed services, as illustrated by this mother:

And then some of them will make appointments knowing full well that they can't keep it because they've got other commitments. [...] You might not see him for about three weeks and then he'll turn up. [...] He had about three different jobs, dithering, and he was like fitting this around his other jobs, that's not what my son needs so I just told him: don't come back.

This mother was frustrated by what she perceived as superficial efforts on the part of agency staff who provided little or no real help, but recognised that they were nevertheless well paid for their efforts:

Social services, probation officers, all these do-gooders, mentors and whatever: it's a job, money coming in their pockets every month, it's nothing more than that. Nobody's interested to really do anything for anybody. [...] They're just interested in making it all look good on paper, they're not really interested. I've had social workers come round here, been in the house five minutes and they're ticking his name off, they've been to see him. [...] I've had to tell them don't bother coming back, love, because if that's all you're going to do, I can tick a paper.

This lack of trust in statutory agencies in some instances lay over a fear that cooperation with agency staff could result in having a gang-involved child - or other children in the family - taken into the care of the state, as this mother describes:

When my son got into trouble first, when he was younger, I begged social services for help 'coz I could see what was coming, but they wouldn't give me no help. You know when they want to give you help? When he actually got himself into trouble, they come round wanting to put him in a home. [...] They then decided they were taking me to court for custody of this child. 


\section{Denial or confusion? The problem of establishing gang status in a child}

The sons of most of the parents we interviewed were widely believed to be gang members (by police, by others in the gang or in other gangs, and by people in their communities). These parents had not always been aware of, or ready to admit to being aware of, the gang activity of their children. This mother attempted to explain why she did not know of her son's gang involvement:

But how would you know? I'm one of these parents who try and bring their kids up in the right way and I just assume that everyone else tries to bring their kids up in the right way. So if you see your son with somebody who you've known their kid, all your life, you've known their parents, you're not automatically going to think oh well he's a bad person, you understand me?

Moreover, there was no change in her son's behaviour at home to alert her:

What your kids do outside or behave outside they don't actually come in your house and behave in that way, so you haven't really got anything to go by. [...] They come in the house and they just act normal and there's nothing to make you think, here you are, hang on a minute, what's going on here?

A number of parents we interviewed questioned the validity of 'association' as conferring gang status. This father's attempts to explain the intricacies of how others came to understand his son's gang status reflect subtle distinctions made when trying to locate someone's 'relational' gang status. All this is consistent with research that demonstrates that gangs are 'messy social networks' (Aldridge and others, 2008), the boundaries of which are fluid and blurred.

[Interviewer: You yourself don’t regard [your son] as a gang associate. Has anybody else, such as the police?] Now I have to be very careful how I answer that. [...] Right, he knows a lot of people, right? He's familiar with a lot of people in the community, a lot of people know him and they know him not only because of me but because of his brothers and things like that, right? Erm, and a lot of those people are affiliated with certain groups or gangs or whatever you want to call them nowadays. [...] So when certain people say, 'oh, he's, he goes round with so and so', and the next day its like, 'wow, he's over there today, so he's with them', you get me? You know how people talk and think, but he's just himself man, he does his own thing.

This mother makes a clear case for the danger of misattributing gang status, and is therefore critical of local strategies that appear to ascribe 'gang member' status via association through proximity, friendship and family ties:

This is why these kids end up in gangs. Half of them are not even gangs, they're just a gang of kids hanging around on the corner. How do you say, well that's a gun gang member, that's a robbing gang member, and that's just a gang that's stood on the corner. How do you distinguish between them groups? If I went out with a friend and she's doing robbing, doing cheque cards or whatever, does that mean because I associate with her that I'm the same as her? [...] My middle son knows certain people. [...] He can't avoid them, he goes to school with them. It's not his fault that they've got cousins or brothers or uncles that were previously gang, so-called gang members. [...] What does that make me then? I associate with him; does that make me a gang mother member? Coz that's basically what they're saying. 


\section{Discussion: implications for implementing parenting interventions}

\section{'Don't blame me': barriers to the engagement of parents in interventions}

The findings of our research are consistent with the view that, in the context of multiple marginality (Vigil, 2002), new or intensive family interventions are likely to need extensive preparatory work that tackles misconceptions about services, denial of problems, and fear of blame and stigmatisation (Kane and others, 2007; McGrath, 2007). Parents may require considerable persuasion to engage them with an intervention:

- Parents should be reassured that the intervention is aimed at supporting rather than judging them. Interventions should not be perceived by parents as starting with the assumption that their parenting is poor: the parents we spoke to thought that their parenting skills were good or even excellent, and resented those who, at the outset, viewed their skills as suspect because of the behaviour of their children.

- The intervention should be presented as recognising that parenting is only one factor in understanding offending and gang involvement in young people. Parents recognised what has been confirmed in the literature: stronger and more consistently supported risk factors exist in domains aside from the family (e.g. delinquent peers in adolescence) (Shute, 2008), and sit alongside poverty and exclusion.

- Parents' fears that their children could be taken into the care of the state need to be addressed upfront.

- Parents were sensitive to stigma. They reported feeling humiliated and ashamed about a child's gang involvement in front of police, other statutory agency staff, neighbours and others in their community, and perceived blame from all these sectors. This suggests that interventions not only need to be seen as palatable to parents, but also publicly packaged in such a way that parents can feel reassured that the wider community is less likely to judge on those taking part as 'to blame' for a child's gang involvement.

- Interventions are likely to be aimed at parents who have already had considerable involvement with statutory agencies through the 'management' of their children through the criminal justice system (Holt, 2009, p. 344), and many will be critical of these agencies. Those seeking to intervene need to anticipate that parents may be on guard. The fact that parents reported dealing with a range of agency staff they perceived to be uncommitted and uncaring suggests that a parenting intervention will be more palatable where staff are highly trained, and perceived by parents as committed, motivated and 'on their side'. An intervention that minimised the number of staff parents needed to deal with, perhaps with one coordinating or key worker, could facilitate this.

\section{Intervening with whom?}

Parents often denied the gang status of a child, even when statutory agencies considered the child to be gang involved. Although this can be read as unwillingness amongst parents to acknowledge the 'truth' (e.g. Jensen, 2008), we conclude that other explanations are as likely. Parents found it difficult to identify gang involvement in a child, or to work out who amongst a child's friends was 'in' a gang. The problem of recognising a gang member is not simply one that vexes parents, it is an ongoing problem for gang researchers, as shown by considerable academic debate about definitions (Aldridge and others, 2008). During our two years in the field, we found that on-the-ground definitions varied widely amongst the police, other statutory agencies, and community members in and outside of gangs in relation to criteria including the 
use of firearms, drug dealing, ethnic minority status, location and more. All this suggests that gearing interventions towards actual problem behaviour (e.g. delinquency, offending), rather than to gang status, may be more understandable and acceptable to parents, and is consistent with the approach taken by other UK commentators (e.g. Bullock and Tilley, 2008).

It is, however, these very parents of children exhibiting problem behaviour that we found to be so resistant to parenting interventions. One implication, therefore, may be to target primary prevention efforts at families with children 'at risk' of gang involvement (say, having an older gang-involved relative), but who do not exhibit these problem behaviours (or, not yet); in effect widening rather than narrowing the net. The idea here is that resistance due to a fear of blame may be less pronounced in these parents, as the child has not been involved in serious delinquency. Indeed, one mother of a gang member suggested that parenting interventions would be better aimed at the often very young women who have young children to gang members: 'They need it, that's needed yeah, they're scared even oh, they can't even speak, they don't want to be with them sometimes but they stay with them'. In spite of the superficial appeal of an approach that seeks to prevent problems before they even start, we are extremely wary of this strategy. The problem is the risk of intervening inappropriately - prediction on the basis of risk factors is nowhere near perfect, and intervention aimed at the families of children who have not demonstrated problem behaviour risks labelling - and engendering through that label - the very behaviour it is seeking to reduce. Net-widening is therefore a double-edged sword. Indeed, some of the parents we spoke to understood that gang 'labels' - often coming from the police as a result of association with 'known' gang members - could result in young people coming to view themselves as gang members, or joining for protection as word spread to rival gangs. Nevertheless, as argued in a recent review (Shute, 2008), multiply marginalised young parents, including those with a recent history of gang-related offending, may benefit from intensive early support; Nurse-Family Partnerships were recommended.

Care should be taken when recommending intervention on the grounds of an as-yet poorly defined notion of 'risk for gang membership'. Although there do not seem to be obvious risk factors that uniquely predict gang membership, given that having existing gang members in the family (e.g. Cohen and others, 1994), as friends (Winfree and others, 1994), as schoolmates (Curry and Spergel, 1992; Curry and Thomas, 1992) and in the community (Nirdorf, 1988), all present risk, it may make practical sense to view the criterion for intervention as 'presenting with actual problem behaviour' plus one or more of these factors as 'risk' for gang membership. A functional approach to understanding 'risk of gang membership' may be to treat it as 'actual problem behaviour in the index child/adolescent' but, where having gang members amongst close family and friends is seen to pose additional risk and to provide a rationale for prioritising support.

The parents of gang members we spoke to were fearful of blame, sensitive to stigma, critical of statutory agencies, and often denied or were confused about the problem behaviour of their children. Although these features need to be acknowledged by those developing parentfocused interventions, they do not mark the parents of gang-involved young people out as strange animals; indeed, they have much in common with parents the world over. What is undoubtedly unique, however, is their disproportionate experience as victims of violence and other crime, alongside their gang-involved children. Parent-focused interventions can have an important role to play in supporting these families through the psychological trauma that accompanies being witnesses to and victims of violent crime (Marans and Cohen, 1993). 


\section{Acknowledgements}

We would like to thank Julie Boyle, Phil Edwards and Yvonne Thorne for their capable and reliable assistance throughout this project. The research was supported by the Economic and Social Research Council (RES-000-23-0615) and by a city council (unnamed, to retain the anonymity of the location of the research).

\section{References}

Aldridge J, Medina J, Ralphs R. 2008. Dangers and problems of doing 'gang' research in the UK. In Street Gangs, Migration and Ethnicity. van Gemert F, Peterson D, Lien I-L (eds). Willan: Cullompton; 31-46.

Bronfenbrenner U. 1979. The Ecology of Human Development. Harvard University Press: Cambridge, MA. Bullock K, Tilley N. 2008. Understanding and tackling gang violence. Crime Prevention and Community Safety 10: 36-47.

Burney E, Gelsthorpe L. 2008. Do we need a naughty step? Rethinking the parenting order after ten years. The Howard Journal of Criminal Justice 47: 470-485.

Clarke K, Churchill H. 2007. Parenting Interventions with the Parents of Adolescents: A Review of Approaches, Programmes and Outcomes. Manchester University: Manchester.

Cohen MI, Wiliams K, Bekelman AM, Crosse S. 1994. Evaluation of the national youth gang drug prevention program. In The Modern Gang Reader. Klein MW, Maxson CL, Miller J (eds). Roxbury: Los Angeles; 266-275.

Curry GD, Spergel IA. 1992. Gang involvement and delinquency among Hispanic and African-American adolescent males. Journal of Research in Crime and Delinquency 29: 273-291.

Curry CD, Thomas RW. 1992. Community organization and gang policy response. Journal of Quantitative Criminology 8: 357-374.

Ghate D, Ramella M. 2002. Positive Parenting: The National Evaluation of the Youth Justice Board's Parenting Programme. Youth Justice Board: London.

Hagedorn JM. 2008. A World of Gangs. University of Minnesota Press: Minneapolis, MN.

Hallsworth S, Young T. 2008. Gang talk and gang talkers: a critique. Crime Media Culture 4: 175-195.

Hawkins JD, Herrenkohl T, Farrington DP, Brewer D, Catalano RF, Harachi TW. 1998. A review of predictors of youth violence. In Serious and Violent Juvenile Offenders: Risk Factors and Successful Interventions. Loeber R, Farrington DP (eds). Sage: Thousand Oaks, CA; 106-146.

Holt A. 2008. Room for resistance? Parenting orders, disciplinary power and the production of the "bad parent'. In ASBO Nation. Squires P (ed.). The Policy Press: Bristol; 203-222.

Holt A. 2009. (En)gendering responsibilities: experiences of parenting a 'young offender'. The Howard Journal of Criminal Justice 48: 344-356.

Howell JC. 1998. Promising programs for youth gang violence prevention and intervention. In Serious and Violent Juvenile Offenders: Risk Factors and Successful Interventions. Loeber R, Farrington DP (eds). Sage: Thousand Oaks, CA; 284-312.

Howell JC. 2000. Youth Gang Programs and Strategies. US Department of Justice, Office for Juvenile Justice and Delinquency Prevention: Washington, DC.

Howell JC, Egley A. 2005. Moving risk factors into developmental theories of gang membership. Youth Violence and Juvenile Justice 3: 334-354.

Jensen S. 2008. Gangs, Politics and Dignity in Cape Town. James Currey: Oxford.

Kane GA, Wood VA, Barlow J. 2007. Parenting programmes: a systematic review and synthesis of qualitative research. Child: Care, Health and Development 33: 784-793.

Klein MW, Maxson CL. 2006. Street Gang Patterns and Policies. Oxford University Press: Oxford.

Koffman L. 2008. Holding parents to account: tough on children, tough on the causes of children? Journal of Law and Society 35: 113-130.

Marans S, Cohen DJ. 1993. Children and inner-city violence: strategies for intervention. In Psychological Effects of War and Violence on Children. Leavitt LA, Fox NA (eds). Lawrence Erlbaum: Hillsdale, NJ; 281-302. 
Maxson CL, Whitlock ML. 2002. Joining the gang: gender differences in risk factors for gang membership. In Gangs in America. Huff CR (eds). Sage: Thousand Oaks, CA; 19-35.

McGrath N. 2007. Engaging the hardest to reach parents in parenting-skills programmes. In How to Reach 'Hard to Reach' Children. Improving Access, Participation and Outcomes. Pomerantz KA, Hughes M, Thompson D (eds). Wiley: Chichester; 184-205.

Miller J. 1998. Gender and victimization risk among young women in gangs. Journal of Research in Crime and Delinquency 35: 429-453.

Moran P, Ghate D, van der Merwe A. 2004. What Works in Parenting Support? A Review of the International Evidence. Policy Research Bureau: London.

Nirdorf BJ. 1988. Gang Alternatives and Prevention Program. Program Policy and Procedure Handbook. County of Los Angeles Probation Department, Los Angeles.

Nixon J, Parr S. 2008. Family intervention projects and efficacy of parenting interventions. In Prevention and Youth Crime: Is Early Intervention Working. Blyth M, Solomon E (eds). Policy Press: Bristol.

Pitts J. 2008. Reluctant Gangsters: The Changing Face of Youth Crime. Willan: Cullompton; 41-52.

Ralphs R, Medina J, Aldridge J. 2009. Who needs enemies with friends like these? The importance of place for young people living in known gang areas Journal of Youth Studies 12: 483-500.

Sharp C, Aldridge J, Medina J. 2006. Delinquent Youth Groups and offending behaviour: findings from the 2004 Offending, Crime and Justice Survey. Home Office Online Reports, Home Office, London.

Short JF, Hughes LA. 2006. Studying Youth Gangs. Altamira Press: Lanham.

Shute J. 2008. Parenting and Gangs: Risk, Resilience and Effective Support. Gang Research Unit, University of Manchester: Manchester.

Smith D, Bradshaw P. 2005. Gang Membership and Teenage Offending, Centre for Law and Society, University of Edinburgh, Edinburgh.

Taylor TJ, Peterson D, Esbensen FA, Freng A. 2007. Gang membership as a risk factor for adolescent violent victimization. Journal of Research in Crime and Delinquency 44: 351.

Thornberry TP. 1998. Membership in youth gangs and involvement in serious and violent offending. In Serious and Violent Juvenile Offenders: Risk Factors and Successful Interventions. Loeber R, Farrington DP (eds). Sage: Thousand Oaks, CA; 147-166.

Thornberry TP, Krohn MD, Lizotte AJ, Chard-Wierschem D. 1993. The role of juvenile gangs in facilitating delinquent behavior. Journal of Research in Crime and Delinquency 30: 55-87.

Thornberry TP, Krohn MD, Lizotte AJ, Smith CA, Tobin K. 2003. Gangs and Delinquency in Developmental Perspective. Cambridge University Press: Cambridge.

Tremblay RE, Masse L, Pagani L, Vitaro F. 1996. From childhood physical aggression to adolescent maladjustment: the Montreal prevention experiment. In Preventing Childhood Disorders, Substance Abuse, and Delinquency. Peters RD, McMahon RJ (eds), 268-298. Sage Publications, Inc.: Thousand Oaks, CA; 268-298.

Vigil JD. 2002. A Rainbow of Gangs. University of Texas Press, Austin.

Vigil JD. 2007. Gang and Non-Gang Families in East Los Angeles. University of Texas Press: Austin.

Warr M. 2007. The tangled web: delinquency, deception, and parental attachment. Journal of Youth and Adolescence 36: 607-622.

Welsh BC, Farrington DP. 2006. Effectiveness of family-based programs to prevent delinquency and later offending. Psicothema 18: 596-602.

Winfree LT Jr, Backstrom TV, Mays GL. 1994. Social learning theory, self-reported delinquency, and youth gangs: a new twist on a general theory of crime and delinquency. Youth and Society 26: 147177.

Youth Justice Board. 2007. Groups, Gangs and Weapons. Youth Justice Board: London.

*Correspondence to: Judith Aldridge, University of Manchester School of Law, Oxford Road, Manchester, Manchester M13 9PL, UK. E-mail: judith.aldridge@manchester.ac.uk

Accepted for publication 17 November 2009 